\title{
Virtual World: A New Paradigm in Brand Marketing
}

\author{
Shubham Shaurav, Sanaullah Mallick
}

\begin{abstract}
The main objective of this research is to measure the potential of in-game advertisement with the relation of brand awareness and brand engagement in the context of placing a different type of advertisement inside the virtual gaming world in the Indian market place. This study utilized a mixed-methods approach divided into two stages, where the first involvement of the collection of qualitative data. The second stage consisted of quantitative data collection through online questionnaires from 160 valid respondents, ranging from the age of 18 to 30 by a non-probability sampling method. SPSS and smart-pls were used to analyze the data with three statistical analysis methods: bivariate correlations, a reliability analysis to test Cronbach alpha for internal consistency; and path analysis in structural equational modeling to examine the relationship between independent and dependent variables. The research findings indicate that there is a positive, significant to place an advertisement in the virtual gaming world and it's also fruitful for brands as per our study. Also, findings indicate that the statistical relationship between brand awareness, brand engagement, advertisement and post-marketing response in the virtual gaming world. As a result, companies operating need to focus on this new paradigm in brand marketing, as the user of the virtual game is increasing day by day and further create a way of gaining competitive advantage.
\end{abstract}

Keywords: Advertisement in the virtual world, Brand Awareness, Brand Engagement, Branding

\section{INTRODUCTION}

$W_{\text {e all are the key witness of how modern games are }}$ acquiring the attention of whole Indian society, especially when PUBG entered in India, we can easily draw a thick line between before and after effect. Nowadays a large segment of Millennials and Post-Millennials are entering into the virtual world of gaming, as a matter of fact, the gaming industry is also booming at a higher pace day-by-day.

As per one study by KPMG consultancy, the Indian online game market is expected to grow at a CAGR of approx.23\%., due to the rise in the smartphone user base, growth of internet penetration and jump in disposable income. Talking about India the major segment of Indian society is young and below 26 years, which is always a major target of the game manufacturers. The report also suggests that currently, the value of the Indian gaming business is \$290 million (Rs2,070 crore) which is expected to grow over \$1 billion with 190 million games by the year 2021 .

We are in a period where the number of virtual worlds is

Revised Manuscript Received on December 12, 2019.

Shubham Shaurav*, Student at Management department, LPU, Phagwara, India. Email: shubhamsaurave15@gmail.com

Sanaullah Mallick, Student at Management department, LPU, Phagwara, India. Email: smallick031@gmail.com

(c) The Authors. Published by Blue Eyes Intelligence Engineering and Sciences Publication (BEIESP). This is an open access article under the CC BY-NC-ND license (http://creativecommons.org/licenses/by-nc-nd/4.0/)
* Correspondence Author

emerging with various purposes and designs. The world is also very successful to acquire a large user base and growing member communities. They have also influenced users for virtual business activities that we refer to as virtual commerce or v-commerce.

The purpose of this research paper is to find the hidden opportunity for the brands to lead to an increase in the number of sales in the real world by using the marketing strategy in the virtual world. There is a big opportunity to target a large segment of society in the virtual world. The brand can also engage their potential customer with their product and can also create recall value as well as real-life brand awareness in the virtual world.

\section{Problem:}

$\checkmark$ Attention Time of Human Being: 12 secs in 20008 secs in 2015 (Study done by Microsoft)

$\checkmark$ Digital Media Engagement: People spend 1.7 seconds on any mobile content 2.5 seconds on desktop content.

$\checkmark$ Challenges for Companies: To create brand awareness and brand engagement

Purpose: "The impact of advertisement in the virtual gaming world on brand awareness, brand engagement and on sales of the respective company"

\section{BACKGROUND}

Two main functions of marketing that every company wants to fulfill are to create brand awareness and brand engagement. That's led a bundle of a research paper in this field, but we have recognized a more hopeful future in virtual gaming and having the potential to beet social media marketing. Brand awareness and brand engagement can be defined as a person's emotional and rational attachment between a consumer and company (Dr. Adam Joinson, 2002). And a virtual gaming world carries both effective tools which help the game to create an emotional moment.

Virtual or in-game content has quickly become one of the biggest appearances of online consumption for virtual gamers which is also creating the revenue model for game publishers (Koskinen, Paavilainen, Hamari \& Alha, 2016; Lehdonvirta, 2009; Hamari, 2015).

In the modern era some traditional approaches of an advertisement becoming ineffective. Looking at the past, it can be seen that the tradition of avoiding an advertisement is very traditional among us as a human being. Always dropping an advertisement has been a historical convention.

The research was done by Microsoft (2015) says, that there is a sharp decrease in the attention span of a human being. The average attention span of human beings was 12 seconds in the year 2000, which is dropped to 8 seconds in a year.

Published By:
Blue Eyes Intelligence Engineering \& Sciences Publication (C) Copyright: All rights reserved.

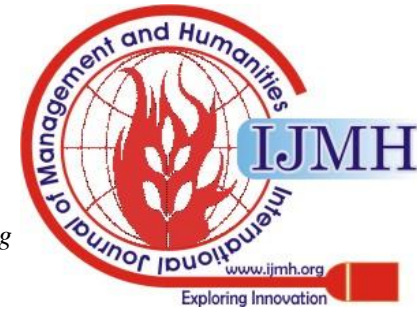


The concept of in-game advertisement is slightly different from traditional approaches, though it's also developed by using the concept of traditional marketing.

While playing the game, we see various products from different companies that are placed inside the game to create brand awareness. Talking about PUBG, recently Streetwear Company BAPE added a few of their products inside the game PUBG.

Companies are trying to innovate a lot of different ways to target their customers differently in the current competitive market place. There are several opportunities in the In-game ads which can boost business sales. Currently, companies are already using many innovating ways to target their customers by using In-game advertisements. In our research paper, we are looking for some more innovative advertisements in the upcoming future and this research paper will help companies in that.

Professional marketers are already using various in-game advertisement technique and these are some ways of In-game ads currently companies are using;

- Load screen: Brands place ads while waiting for gameplay to begin.

- Gameplay areas: From billboards and mega posters in city streets to trackside hoardings in sports and racing games.

- Menu screens: Gives ad visibility while gamers customize options.

- Lobby screens: Ad in pre -and- post- game activity and chat.

- Interstitial screens: An ad that is inserted in between option screens.

- Audio: It delivers seamless audio messaging without disrupting gameplay.

- Video: 5-30 seconds full-motion video delivered to in--game video screens in billboard format, or into loading or interstitial screens for a truly captive audience.

- 3D objects: Almost any conceivable 3-dimensional object such as a corporate logo or the latest product are modeled/placed and dynamically served as background objects.

\section{OBJECTIVES}

To answer the proposed research question, the following objectives are presented:

$\checkmark$ Check the consumer's post-marketing response in the virtual world.

$\checkmark$ How to formulate the new marketing strategy

$\checkmark$ Whether it will be a strong part of marketing tools in the upcoming future?

\section{CONCEPTUAL MODEL AND HYPOTHESES}

The conceptual model for this study assumes that the perfect way to explain the impact of the independent variable, brand awareness, brand engagement, efficiency, and marketing strategy building on the dependent variable, the post-marketing response is by using a third variable, the virtual world is the best place for advertisement

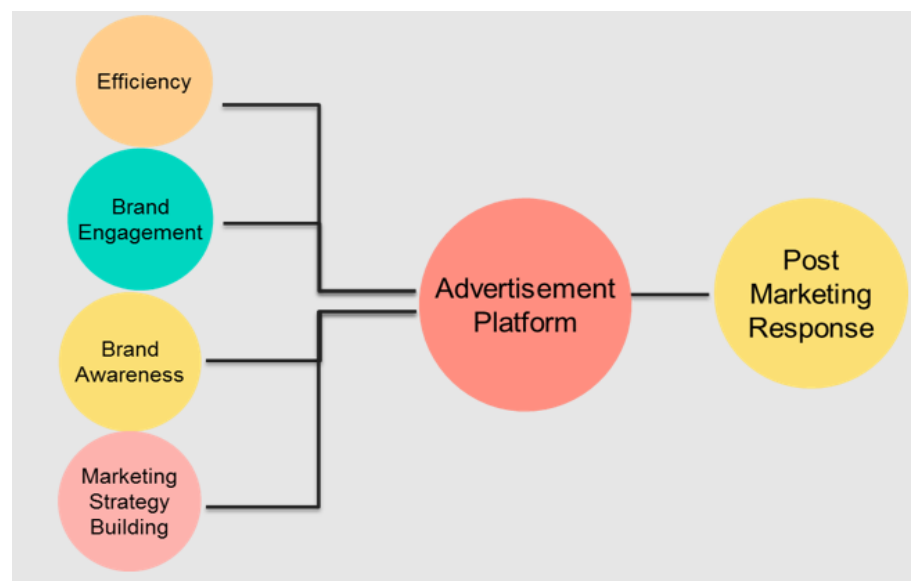

H1: At least one construct of brand awareness is significantly, positively associated with advertisement platforms.

$\mathbf{H}_{2}$ : At least one construct of brand engagement is significantly, positively associated with advertisement platforms.

Н3: At least one construct of efficiency is significantly, positively associated with the advertisement platform.

$\mathbf{H}_{4}$ : At least one construct of marketing strategy building is significantly, positively associated with advertisement platforms.

$\mathbf{H}_{5}$ : Advertisement platform is significantly, positively associated with post-marketing response

H6: Advertisement platform mediates the relationship between brand awareness, brand engagement, efficiency, marketing strategy building and post-marketing response.

\section{RESEARCH METHODOLOGY}

\section{A. Research Design}

The two stages processed was used in the whole study of this research paper, which is based on the research question: a qualitative research stage, supported by a descriptive quantitative research stage. The exploratory research was attempted to begin with the research project to the efficient literature reviewed of the previous research available on online sources.

\section{B. Research Approach}

We have used a mixed approach of both "qualitative" and "quantitative". As a qualitative approach, we have done a literature review of 20 related research articles. As a quantitative tool, we collected the primary data by online questionnaire survey and the data has been analyzed by using a statistical tool like SPSS, Smart-pls.

\section{Sample Method and Sample Size}

In this study "non-probability sampling" method has been used to select the appropriate target sample to reach a rational conclusion.

Sample Size: 160 [75\% Male (120), 25\% Female (40)]

Age Group: 18 years to 50 years

Target Sample: PUBG Player

Location: India

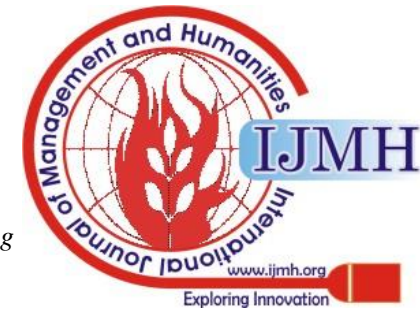


Thus, to answer the survey we asked 250+ potential respondents out of which a total of approx. 160 provided complete responses of all respondents who already playing PUBG game,

\section{Data Collection Methods (Primary And Secondary)}

Primary: The primary data was collected using an online questionnaire on google docs. The questionnaire was circulated to respondents from various states in India.

Secondary: As a source of secondary data source we used a various source like;

- Articles

- Journals

- Books

- Web Source

- Institutional Reports

\section{E. Data Analysis Methods}

To measure the reliability of each construct of the questionnaire, a reliability test was done in the SPSS tool by using "Cornbach Alpha Test", and we got a strong reliability coefficient of 0.79 . To analyze the data various statistical tools have been used. We measured "multiple correlations" and "multi-collinearity" among all the constructs of the questionnaire. A "Structural Equation Model" has also been constructed by using the Smart-pls tool.

\section{MEASUREMENT INSTRUMENTS}

The main purpose of this study was to explore the factors of advertisement in virtual gaming affect brand awareness, brand engagement on sales and revenue of the respective company. Therefore, it was necessary to obtain multiple observable items from each dimension of advertisement in virtual gaming, representing relevant aspects of PUBG game for measuring the success of advertisement campaigns in the virtual gaming world indirectly as a latent variable.

\section{A. Efficiency}

The efficiency construct in the virtual gaming world, we select PUBG for this research is defined as the, if any company place an advertisement in the virtual gaming world is that ads got visible to players to what extent the user effectively response the advertisement will playing when it comes to the following questions:

$>$ How much time do you spend in a day for playing games?

$>$ Do you notice the big banner around while playing the game?

$>$ Have you ever thought of owning a product that you own in gaming life?

$>$ Do you remember this logo in PUBG?

$>$ Does the use of in--game advertisements distract you from the game?

Respondents were also asked to rate different types of in-game advertisements in order to gather the general attitude towards each type of advertisement.

\section{B. Marketing Strategy Building}

We tried to identify how well we can build strategies and is those strategies are acceptable by the target customer or not for that there some question related to that which help to measure the effectiveness of strategy building are following:
$>$ Would you like to have the chicken dinner's chicken in a KFC bucket inside PUBG?

$>$ Would you like to have woodland or any other branded shoes in PUBG?

$>$ Would you like to have a branded and labeled product inside PUBG?

$>$ If you find CCD/Star bucks in-side PUBG would you like to visit there?

$>$ Do you like to share your in-game experience with your close friends?

\section{Post-Marketing Response}

There is some advertisement already running on that platform but on other hands, there are some in-game products which related to real-world product and by the survey of this research the impact created on a real brand by that, are also try to measure by following questions:

$>$ When you see an energy drink inside PUBG what brand do you recall in mind?

$>$ Do you remember this logo in PUBG?

$>$ Have you ever use products from BAPE crate in PUBG?

$>$ Have you ever bought energy drinks in real life as an influence of having energy drink inside the game, while playing PUBG?

$>$ Have you ever purchased a product in the real world after watching it in PUBG or any other game?

\section{Brand Awareness}

Is the platform is helpful or not. Respondents were asked to indicate their answers.

$>$ When you see an energy drink inside PUBG what brand do you recall in mind?

$>$ Do you remember this logo in PUBG?

$>$ Have you ever use products from BAPE crate in PUBG?

$>$ Have you ever bought energy drinks in real life as an influence of having energy drink inside the game, while playing PUBG?

$>$ If you find CCD/Star bucks in-side PUBG would you like to visit there?

$>$ Would you like to have the chicken dinner's chicken in a KFC bucket inside PUBG?

\section{E. Brand Engagement}

We also try to measure how much virtual games like PUBG can help any brand into an engagement.

$>$ How much time do you spend in a day on playing games?

$>$ Do you spend real-life money to purchase any digital product in gaming life?

$>$ Do you like to spend money to personalize your character inside a game?

$>$ Does the product/object inside games relate to your daily life?

$>$ Have you ever thought of owning a product that you own in gaming life?

$>$ Would you like to have woodland or any other branded shoes in PUBG?

$>$ If you find CCD/Star bucks in-side PUBG would you like to visit there?

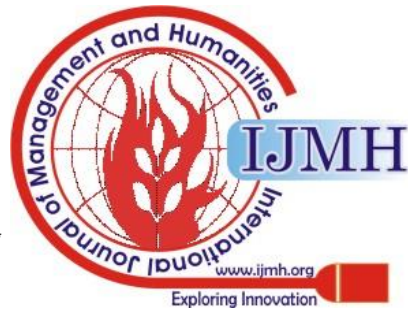


$>$ Would you like to have the chicken dinner's chicken in a KFC bucket inside PUBG?

$>$ Would you like to have a branded and labeled product inside PUBG?

\section{RESULT}

\section{A. Efficiency}

There are some question from which we can interpret that more the $75.6 \%$ respondent spend time on virtual gaming world between 1-3 hours per day that means that at least one's in a day almost every response visits virtual gaming world, and we also find that $60 \%$ plus respondents also notice the banner which is used inside game. Most of the time 38\% of respondents thinks about to own the product which they find in the virtual gaming world and $36 \%$ of respondents think about it for the same. Hence, we can say that $75 \%$ of the total population thinking about to own some product of the virtual world. $34 \%$ of respondents are also able to recognize the logo which we presented in our questionnaire and $80 \%$ approx players sometimes distract from the game. Lastly, we can say that all the questions and their responses were given by the respondent's point that marketing in the virtual world of gaming is beneficial for brands and nowadays people are giving more attention to a brand in the virtual world of gaming.

\begin{tabular}{|c|c|c|}
\hline 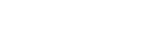 & Frequency & Percentage \\
\hline \multicolumn{3}{|c|}{ How much time do you spend in a day on playing games? } \\
\hline$<3$ hours & 121 & $75.6 \%$ \\
\hline $3-5$ hours & 32 & $20 \%$ \\
\hline $5-7$ hours & 3 & $1.9 \%$ \\
\hline$>8$ hours & 4 & $2.5 \%$ \\
\hline \multicolumn{3}{|c|}{ Do you notice the big banner around while playing a game? } \\
\hline Yes & 99 & $61.9 \%$ \\
\hline No & 26 & $16.2 \%$ \\
\hline May be & 35 & $21.9 \%$ \\
\hline \multicolumn{3}{|c|}{$\begin{array}{l}\text { Have you ever thought of owning a product that you own in } \\
\text { gaming life? }\end{array}$} \\
\hline Sometimes & 59 & $36.9 \%$ \\
\hline Often & 61 & $38.1 \%$ \\
\hline Never & 40 & $25 \%$ \\
\hline \multicolumn{3}{|c|}{ Do you remember this logo in PUBG? } \\
\hline Yes & 54 & $33.8 \%$ \\
\hline No & 48 & $30 \%$ \\
\hline May be & 42 & $26.2 \%$ \\
\hline Don't remember & 16 & $10 \%$ \\
\hline \multicolumn{3}{|c|}{$\begin{array}{l}\text { Does the use of in-game advertisements distract you from the } \\
\text { game? }\end{array}$} \\
\hline Sometimes & 82 & $51.2 \%$ \\
\hline Often & 48 & $30 \%$ \\
\hline Never & 30 & $18.8 \%$ \\
\hline
\end{tabular}

\section{B. Marketing Strategy Building}

We can summaries that the many of sample strategy which we have selected for study is accepted and many of responded are strongly agree to apply that strategy in the virtual gaming world. More than $73 \%$ sample want chicken dinner's chicken in a KFC bucket inside PUBG, and there are $70 \%+$ sample want to be branded and labeled product inside PUBG. And also $70 \%$ of the sample wants to visit familiar branded places So, these strategies can be used by the big brand for promoting their brands.

\begin{tabular}{|c|c|c|}
\hline & Frequency & Percentage \\
\hline \multicolumn{3}{|c|}{$\begin{array}{l}\text { Would you like to have the chicken dinner's chicken in a KFC } \\
\text { bucket inside PUBG? }\end{array}$} \\
\hline Strongly Disagree & 12 & $7.5 \%$ \\
\hline Disagree & 8 & $5 \%$ \\
\hline Neutral & 23 & $14.4 \%$ \\
\hline Agree & 27 & $16.9 \%$ \\
\hline Strongly Agree & 90 & $56.2 \%$ \\
\hline \multicolumn{3}{|c|}{$\begin{array}{l}\text { Would you like to have woodland or any other branded shoes } \\
\text { in PUBG? }\end{array}$} \\
\hline Strongly Disagree & 13 & $8.1 \%$ \\
\hline Disagree & 7 & $4.4 \%$ \\
\hline Neutral & 29 & $18.1 \%$ \\
\hline Agree & 41 & $25.6 \%$ \\
\hline Strongly Agree & 70 & $43.8 \%$ \\
\hline \multicolumn{3}{|c|}{$\begin{array}{l}\text { Would you like to have a branded and labelled product tinside } \\
\text { PUBG? }\end{array}$} \\
\hline Strongly Disagree & 14 & $8.8 \%$ \\
\hline Disagree & 3 & $1.9 \%$ \\
\hline Neutral & 31 & $19.4 \%$ \\
\hline Agree & 41 & $25.6 \%$ \\
\hline Strongly Agree & 71 & $44.4 \%$ \\
\hline \multicolumn{3}{|c|}{$\begin{array}{l}\text { If you find CCD/Star bucks in-side PUBG would you like to visit } \\
\text { there? }\end{array}$} \\
\hline Strongly Disagree & 14 & $8.8 \%$ \\
\hline Disagree & 5 & $3.1 \%$ \\
\hline Neutral & 29 & $18.1 \%$ \\
\hline Agree & 39 & $24.4 \%$ \\
\hline Strongly Agree & 73 & $45.6 \%$ \\
\hline \multicolumn{3}{|c|}{$\begin{array}{l}\text { Do you like to share your in-game experience with your close } \\
\text { friends? }\end{array}$} \\
\hline Strongly Disagree & 18 & $11.2 \%$ \\
\hline Disagree & 22 & $13.8 \%$ \\
\hline Neutral & 42 & $26.2 \%$ \\
\hline Agree & 38 & $23.8 \%$ \\
\hline Strongly Agree & 40 & $25 \%$ \\
\hline
\end{tabular}

\section{Post-Marketing Response}

There is a Japanese clothing brand whose name is BAPE are promoting their products and banner in the virtual gaming world PUBG, to grab the opportunity. So we have also tried to identify the after advertisement effect all those some respondents are not able to recognize that brand because of less presence of that brand in India. but stile many people at least know about that brand because of the presence in the virtual game which is a very positive sign for that platform to also become an advertisement platform. And everyone all remembers the brand red bull by view the same kind of energy drink in the game. And $69 \%$ of people also converted into potential customers after these advertisements.

\begin{tabular}{|c|c|c|}
\hline & Frequency & Percentage \\
\hline \multicolumn{3}{|c|}{ When you see an energy drink inside PUBG what brand do you recall in } \\
\hline Monster & 14 & $8.8 \%$ \\
\hline Red bull & 130 & $81.2 \%$ \\
\hline Ocean one8 & 11 & $6.9 \%$ \\
\hline Other & 5 & $3.1 \%$ \\
\hline \multicolumn{3}{|l|}{ Do you remember this logo in PUBG? } \\
\hline Yes & 54 & $33.8 \%$ \\
\hline No & 48 & $30.0 \%$ \\
\hline May be & 42 & $26.2 \%$ \\
\hline Don't Remember & 16 & $10.0 \%$ \\
\hline \multicolumn{3}{|c|}{ Have you ever used products from BAPE crate in PUBG? } \\
\hline Yes & 78 & $48.8 \%$ \\
\hline No & 62 & $38.8 \%$ \\
\hline May be & 12 & $7.5 \%$ \\
\hline Don't Remember & 8 & $5.0 \%$ \\
\hline \multicolumn{3}{|c|}{$\begin{array}{l}\text { Have you ever bought energy drink in real life as an influence of having } \\
\text { energy drink inside the game, while playing PUBG? }\end{array}$} \\
\hline Sometimes & 38 & $23.8 \%$ \\
\hline Often & 29 & $18.1 \%$ \\
\hline Never & 58 & $36.2 \%$ \\
\hline Interested but not purchased & 35 & $21.9 \%$ \\
\hline \multicolumn{3}{|c|}{$\begin{array}{l}\text { Have you ever purchased a product in the real world after watching it in } \\
\text { PUBG or any other game? }\end{array}$} \\
\hline Sometimes & 26 & $16.2 \%$ \\
\hline Often & 17 & $10.6 \%$ \\
\hline Never & 59 & $36.9 \%$ \\
\hline nink of it & 58 & $36.2 \%$ \\
\hline
\end{tabular}

Published By:

Blue Eyes Intelligence Engineering \& Sciences Publication

(C) Copyright: All rights reserved. 


\section{Brand Awareness}

As we have discussed all why and how brand awareness helpful in the digital gaming world. So we have also measured the same. Further, we have analyzed those responses of respondents, from the analysis we can surely say that any company can create brand awareness in the virtual gaming world, all respondent is aware of the brand with relate to project.

\begin{tabular}{|c|c|c|}
\hline & Frequency & Percentage \\
\hline \multicolumn{3}{|l|}{ When you see an energy drink inside PUBG what brand do you recall in } \\
\hline Monster & 14 & $8.8 \%$ \\
\hline Red bull & 130 & $81.2 \%$ \\
\hline Ocean one8 & 11 & $6.9 \%$ \\
\hline Other & 5 & $3.1 \%$ \\
\hline \multicolumn{3}{|l|}{ Do you remember this logo in PUBG? } \\
\hline Yes & 54 & $33.8 \%$ \\
\hline No & 48 & $30.0 \%$ \\
\hline May be & 42 & $26.2 \%$ \\
\hline Don't Remember & 16 & $10.0 \%$ \\
\hline \multicolumn{3}{|l|}{ Have you ever used products from BAPE crate in PUBG? } \\
\hline Yes & 78 & $48.8 \%$ \\
\hline No & 62 & $38.8 \%$ \\
\hline May be & 12 & $7.5 \%$ \\
\hline Don't Remember & 8 & $5.0 \%$ \\
\hline \multicolumn{3}{|l|}{$\begin{array}{l}\text { Have you ever bought energy drink in reall life as an influence of having } \\
\text { energy drink inside the game, while playing PUBG? }\end{array}$} \\
\hline Sometimes & 38 & $23.8 \%$ \\
\hline Often & 29 & $18.1 \%$ \\
\hline Never & 58 & $36.2 \%$ \\
\hline Interested but not purchased & 35 & $21.9 \%$ \\
\hline \multicolumn{3}{|l|}{ If you find CCD/Star bucks in-side PUBG would you like to visit there? } \\
\hline Strongly Disagree & 14 & $8.8 \%$ \\
\hline Disagree & 5 & $3.1 \%$ \\
\hline Neutral & 29 & $18.1 \%$ \\
\hline Agree & 39 & $24.4 \%$ \\
\hline \multirow{2}{*}{\multicolumn{3}{|c|}{$\begin{array}{l}\text { Would you like to have the chicken dinner's chicken in a KFC bucket } \\
\text { inside PUBG? }\end{array}$}} \\
\hline & & \\
\hline Strongly Disagree & 12 & $7.5 \%$ \\
\hline Disagree & 8 & $5.0 \%$ \\
\hline Neutral & 23 & $14.4 \%$ \\
\hline Agree & 27 & $16.9 \%$ \\
\hline Strongly Agree & 90 & $56.2 \%$ \\
\hline
\end{tabular}

\section{E. Brand Engagement}

In order for to Brand engagement virtual world is one of the best places for the same as per the response we got from the survey, almost every respondent at least spend one hour in the virtual gaming world, and $30 \%$ approx respondents also spend some real money and also buy some product in real life. As per the analysis, we found that almost behavior of every person showing a green flag to brand engagement, and the company can easily create brand engagement with some simple strategies

\begin{tabular}{|c|c|c|}
\hline & Frequency & Percentage \\
\hline \multicolumn{3}{|c|}{ How much time do you spend in a day on playing games? } \\
\hline$<3$ hours & 121 & $75.6 \%$ \\
\hline $3-5$ hours & 32 & $20 \%$ \\
\hline $5-7$ hours & 3 & $1.9 \%$ \\
\hline$>8$ hours & 4 & $2.5 \%$ \\
\hline \multicolumn{3}{|c|}{$\begin{array}{l}\text { Do you spend real-life money to purchase any digital product in gaming } \\
\text { life? }\end{array}$} \\
\hline Sometimes & 27 & $16.9 \%$ \\
\hline Often & 19 & $11.9 \%$ \\
\hline Never & 41 & $25.6 \%$ \\
\hline Interested but not purchased & 73 & $45.6 \%$ \\
\hline \multicolumn{3}{|c|}{$\begin{array}{l}\text { Do you like to spend money to personalize your character inside a } \\
\text { game? }\end{array}$} \\
\hline Sometimes & 36 & $22.5 \%$ \\
\hline Often & 28 & $17.5 \%$ \\
\hline Never & 44 & $27.5 \%$ \\
\hline Interested but never spent & 52 & $32.5 \%$ \\
\hline \multicolumn{3}{|c|}{ Does the productobject inside games relate to your daily life? } \\
\hline Sometimes & 66 & $41.2 \%$ \\
\hline Often & 44 & $27.5 \%$ \\
\hline Never & 50 & $31.2 \%$ \\
\hline \multicolumn{3}{|c|}{ If you find CCD/Star bucks in-side PUBG would you like to visit there? } \\
\hline Strongly Disagree & 14 & $8.8 \%$ \\
\hline Disagree & 5 & $3.1 \%$ \\
\hline Neutral & 29 & $18.1 \%$ \\
\hline Agree & 39 & $24.4 \%$ \\
\hline Strongly Agree & 73 & $45.6 \%$ \\
\hline \multicolumn{3}{|c|}{$\begin{array}{l}\text { Would you like to have the chicken dinner's chicken in a KFC bucket } \\
\text { inside PUBG? }\end{array}$} \\
\hline Strongly Disagree & 12 & $7.5 \%$ \\
\hline Disagree & 8 & $5.0 \%$ \\
\hline Neutral & 23 & $14.4 \%$ \\
\hline Agree & 27 & $16.9 \%$ \\
\hline Strongly Agree & 90 & $56.2 \%$ \\
\hline
\end{tabular}

Retrieval Number: D0469124419/2019@BEIESP

DOI:10.35940/ijmh.D0469.124419

Journal Website: www.ijmh.org

\begin{tabular}{|lll|}
\multicolumn{1}{ll}{} & Frequency & Percentage \\
\hline Have you ever thought of owning a product that you own in gaming life? & & \\
\hline Sometimes & 59 & $36.9 \%$ \\
Often & 61 & $38.1 \%$ \\
Never & 40 & $25.0 \%$ \\
\hline Would you like to have woodland or any other branded shoes in PUBG? & & \\
\hline Strongly Disagree & 13 & $8.1 \%$ \\
Disagree & 7 & $4.4 \%$ \\
Neutral & 29 & $18.1 \%$ \\
Agree & 41 & $25.6 \%$ \\
Strongly Agree & 70 & $43.8 \%$ \\
\hline Would you like to have a branded and labelled product inside PUBG? & & \\
\hline Strongly Disagree & 14 & $8.8 \%$ \\
Disagree & 3 & $1.9 \%$ \\
Neutral & 31 & $19.4 \%$ \\
Agree & 41 & $25.6 \%$ \\
Strongly Agree & 71 & $44.4 \%$ \\
\end{tabular}

\section{HYPOTHESIS TESTING}

Brand Awareness: In the first model, the six constructs of brand awareness were considered as independent variables and the overall advertisement platform, has been considered as the dependent variable. From the below SEM model, the calculated R2 value is 0.896 among the constructs of brand awareness and advertisement platform. From the obtained value it can be concluded that $89.6 \%$ of the variation in overall advertisement platform could be explained by all six constructs of the model and each construct of brand awareness is positively correlated with the advertisement platform.

Brand Engagement: In the second model, the nine constructs of brand engagement were taken as independent variables and the overall advertisement platform, has been considered as the dependent variable. In the below figure of SEM, a value of adjusted R2 $=0.095$ was obtained in this model. Thus, it could be noted that $9.5 \%$ of the variation in the overall advertisement platform could be explained by all nine constructs.

The results of the multiple regression analysis showed that five out of nine constructs of brand engagement were significantly, positively correlated to the overall advertisement platform.

Efficiency: Coming to the third model, thirteen constructs of efficiency were considered as independent variables whereas the mediator, overall advertisement platform, has been considered as the dependent variable. As shown in the figure of SEM, a value of adjusted R2 $=0.24$ was obtained in this model. Thus, it could be noted that $24 \%$ of the variation in the overall advertisement platform could be explained by all thirteen constructs. The results of the multiple regression analysis showed that eight out of thirteen constructs of efficiency were significantly, positively correlated to the overall advertisement platform.

Marketing Strategy: In the fourth model, the five constructs of marketing strategy building were considered as independent variables whereas the mediator, overall advertisement platform, was considered as the dependent variable. A value of adjusted $\mathrm{R} 2=.115$ was obtained in this model. Thus, it could be noted that $11.5 \%$ of the variation in the overall advertisement platform could be explained by all thirteen constructs. The results of the analysis showed that out of five all constructs of efficiency were

Published By:

Blue Eyes Intelligence Engineering \& Sciences Publication

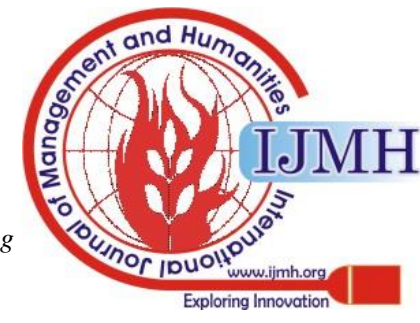




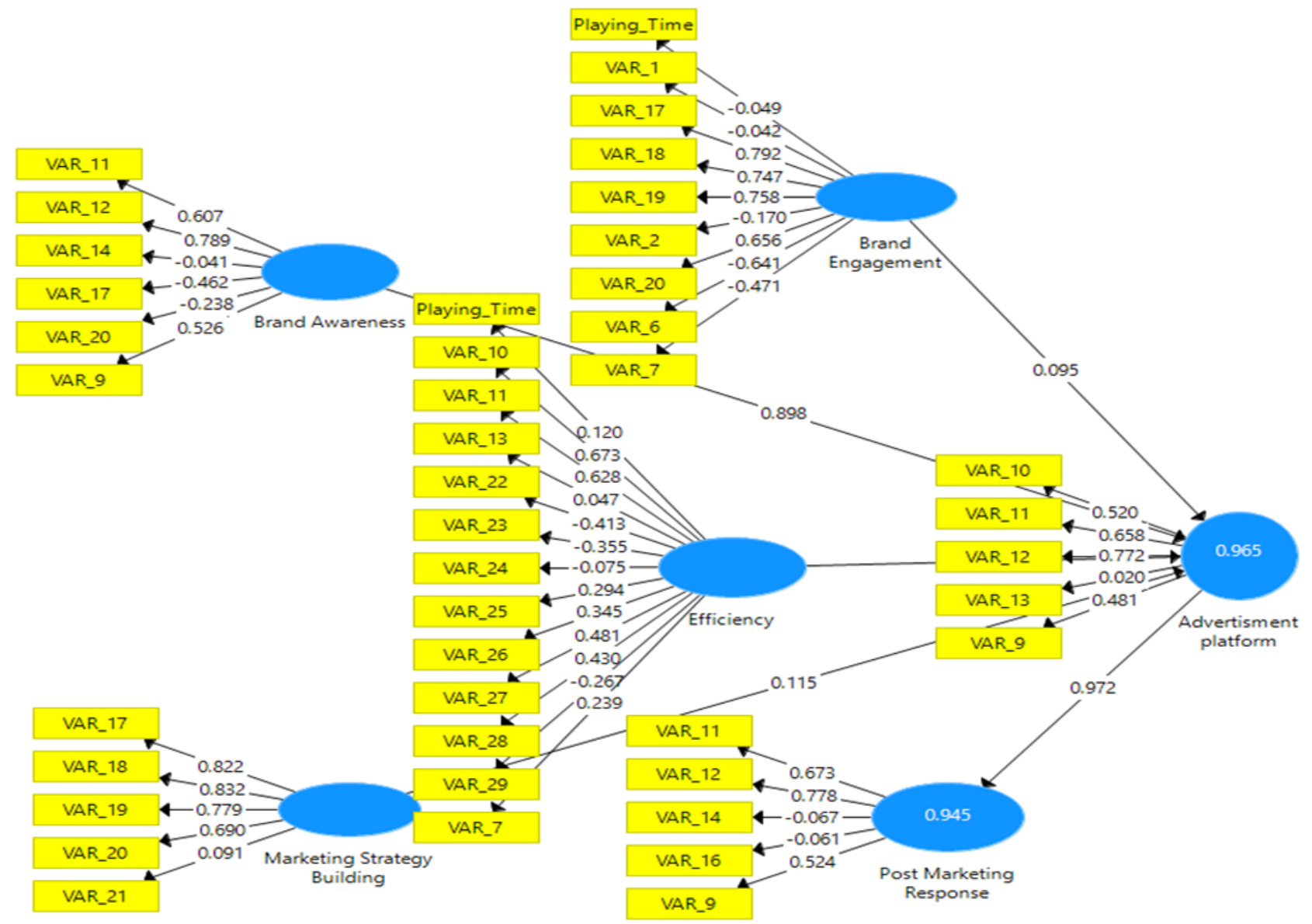

significantly, positively correlated to overall advertisement platform. Hence the construct of marketing strategy building positively associated with the overall advertisement platform.

Post Marketing Response: In the fifth model the post-marketing response was considered as dependent variables while the overall advertisement platform, has been considered as the dependent variable. A value of adjusted $\mathrm{R} 2=.972$ was obtained in this model. It can be noted that $97.2 \%$ of the variation in the overall advertisement platform could be explained by all five constructs. The result shows that out of five three constructs of post-marketing response were significantly, positively correlated to the overall advertisement platform. Hence, the construct satisfaction of fulfillment-library of content is increased, overall been the best advertisement platform chance is also increased.

All Factors vs Advertising Platform: The final regression model treated all measures of advertisement platform for brand engagement, brand awareness, efficiency, and marketing strategy building as independent variables along with overall advertisement platform, whereas post-marketing response was considered as the dependent variable. The adjusted R2 obtained was 0.965 , indicating that $96.5 \%$ of the variation in the dependent variable can be explained by the dependent variable. Hence all the factors are strongly correlated to the overall advertisement platform and post-marketing responses.

\section{CONCLUSION}

The study of research suggest that advertisement in online virtual gaming world has a significant impact on overall brand reorganization and brand engagement for the sample, In fact, findings indicate that many of people are ok with different type of strategy of advertisement in virtual and even the response of sample people is showing very positive sign for advertisement in virtual world. Based on the findings, two main constructs of advertisement

Based on the findings, six constructs of brand awareness including fulfillment-library of indicated a significantly positive correlation with the overall advertisement platform.

Therefore, H0 for hypothesis 1 was rejected, as there is indeed at least one construct of brand awareness that is significantly, positively associated with the advertisement platform.

Moreover, research findings also indicated a direct relation between four constructs of brand awareness, brand engagement, efficiency, marketing strategy building and post-marketing response. H0 for hypothesis 6 was, therefore, also rejected; there is indeed a significantly positive association between at least one construct of the Advertisement platform mediates the relationship between brand awareness, brand engagement, efficiency, marketing strategy building and post-marketing response.

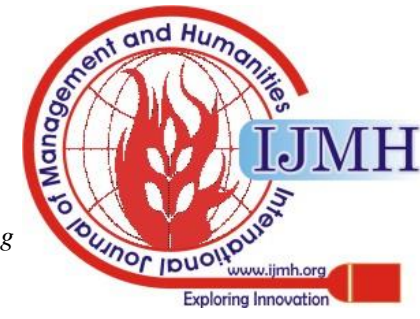


Concerning hypothesis 5, findings indicated that overall advertisement positively associated with post-marketing strategy Based on the research findings, the post-marketing response is considerably increased when the overall detriment is increased. Hence, $\mathrm{H} 0$ for hypothesis 5 was rejected and the alternative hypothesis could be accepted, as overall customer satisfaction is significantly, positively associated with brand loyalty.

Furthermore, in the fourth regression model, brand loyalty was considered as the dependent variable and overall advertisement was added to the model as an independent variable together with the satisfaction constructs of post-marketing response. This indicated that a post has a meaningful linear relation with both the overall advertisement platform and at least certain constructs of a different factor. Also, post-marketing response significantly increased when the overall advertisement platform was increased. As a result, the relationship between the constructs of questioner and brand engagement is partially mediated by advertisement. Therefore, H0 for hypothesis 4 was rejected. Lastly, the results of the regression analyses conducted in this research do not show a cause-and-effect relationship between independent and dependent variables. The regression analysis is merely a tool that assumes a statistical relationship and explains how each factor influences the dependent variable, and to what extent. Hence, it is not possible to conclude that an improved variable will result in increased advertisement platform selection and post-marketing responses. Taking the multiple regression findings into consideration, however, research findings indicate that PUBG in the Indian market should emphasize their efforts toward to become the best advertisement that was identified in this study, as it may improve the overall chance to select a gaming platform for advertisement 15 to 25-year-old users. It may also facilitate the creation of different advertisement strategies for the virtual gaming world in a competitive advantage.

- The postmarketing response is positively affected by the advertisement in the virtual world(0.972).

- There is a strong relationship between brand awareness, brand engagement, efficiency, marketing strategy building and post-marketing response.

- This is the new paradigm in brand marketing, as the user of virtual games continues to grow day by day and is one way to gain further competitive advantage.

\section{SUGGESTIONS FOR FURTHER RESEARCH}

Further research on the subject should adopt, and refine constructs as well as items utilized in this study. As services that do not rely on subscriptions were disregarded from this study, future research could investigate this area to compare the two. A qualitative study with a company perspective could be conducted, to identify how executives manage these questions.
The research could focus on which factors of service quality the executives believe are of most importance, and investigate whether resources are allocated accordingly. Perhaps other methods to achieve loyal customers are utilized, that this study failed to recognize.

\section{LIMITATIONS}

Despite the potential contribution the research could bring to an existing in-game advertisement in the virtual world, there are some unanticipated and anticipated flaws and barriers which presented and suggestions for further research. The reader should note that one important which may have influenced the analysis of the collected data is the sample bias in the chosen sampling method. Because the study is based on data is from a national sample that was selected based on a non-probability sampling method, the representativeness of the sample may be questionable. However, the sampling method was selected due to the limited ability to gain access to a master list. Although efforts were made to enhance the representativeness of the sample being studied, care should still be exercised in generalizing the findings to the entire population as well as to other populations and countries. Also, studying a greater sample size would have enhanced the ability to generalize the findings.

Another important limitation of this research is the concern for non-response surveys. The appropriate sample size was determined to include 250 samples. However, as it was anticipated that not everyone would respond to the questionnaire, a total of 160 questionnaires were sent out.

\section{ACKNOWLEDGMENT}

We would like to acknowledge everyone who has been a part of our research paper and we are thankful for their contribution and involvement in the research project. First of all, we would like to express special thanks of gratitude to our tutor and guide, Mr. Kawalpreet Singh who has helped and guided by providing proper guidance and support throughout the research project.

Furthermore, we would also like to extend our gratitude and thanks to all respondents who have been a part of our survey and gave their special input to complete the survey.

Last but not least, we would like to acknowledge with much appreciation the crucial role of the whole teaching team of Mittal school of business (LPU) for providing such opportunity with clear guidelines and instructions throughout the research project.

This research paper would not have been completed without the concerned parties immense help and support. Thank you indeed!

\section{REFERENCES}

1. Atli, D., \& Can, T. (2015). Advertising in Virtual Worlds: The Example of Second Life.

2. Advertising in $3 \mathrm{D}$ or Virtual Worlds (Second Life), http://emergingadvertisingmedia.wikispaces.com/Advertising+in+3D+or+Virtual+Wor 1ds “2015 April 22”

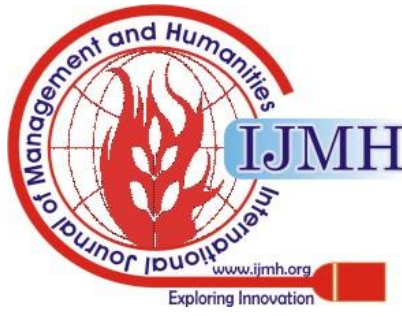


3. Bainbridge, W. S. (2007). The Scientific Research Potential of Virtual Worlds. Science, New Series, 317(5837), 472-476.

4. Barnes, S. (2007). Virtual worlds as a medium for advertising. ACM SIGMIS Database, 38(4), 45. http://doi.org/10.1145/1314234.1314244

5. Barnes, S. J., \& Mattsson, J. (2011). Virtual World. Journal of Marketing Management, 27(August), 934-958. http://doi.org/10.1080/0267257X.2011.565686

6. Boelstorff, T. (2008). Coming of Age in Second Life. Princeton, NJ (USA): Princeton University (1. ed.). New Jersey USA: Princeton University Press. Retrieved from http://scholar.google.com/scholar?hl=en\&btnG=Search\&q=intitle:Com ing + of + Age + in + Second + Life\# 2

7. Book, B. (2004). Moving beyond the game: social virtual worlds. State of Play, (October 2004).

8. Buha, V., Janičić, R., Filipović, V., \& Gligorijević, M. (2011). Virtual Reality in Distance Education and Marketing Communications. International Journal Management-Management-Časopis Za Teoriju I Praksu Menadžmenta, 16(60), 50-59.

9. Chang, C. H., Hsieh, K. Y., Chiang, M. C., \& Wu, J. L. (2010). Virtual spotlighted advertising for tennis videos. Journal of Visual Communication and Image Representation, 21(7), 595-612. http://doi.org/10.1016/j.jvcir.2010.03.006

10. Downey, B. S. (2014). History of the (Virtual) Worlds. The Journal of Technology Studies, 40(2), 54-67.

11. Duncan, I., Miller, A., \& Jiang, S. (2012). A taxonomy of virtual world usage in education. British Journal of Educational Technology, 43(6), 949-964. http://doi.org/10.1111/j.1467-8535.2011.01263.x

12. Fiedler, M. (2009). Cooperation in Virtual Worlds, (April), 173-195.

13. Fornäs, Johan, Kajsa Klein, Martina Ladendorf, Jenny Sundén, and Malin Sveningsson. (2002). "Into Digital Borderlands." In Digital Borderlands: Cultural Studies of Identity and Interactivity on the Internet, ed. Johan Fornäs, Kajsa Klein, Martina Ladendorf, Jenny Sundén, and Malin Sveningsson, 1-47. New York: Peter Lang.

14. Goldman, R., \& Papson, S. (1994). Advertising in the age of hypersignification.Theory, Culture \& Society, 11(3), 23-53.

15. Gabisch, J.A., \& Gwebu, K.L. (2011). Impact of Virtual Brand Experience on Purchase Intentions: The Role of Multichannel Congruence.

16. Goel, L., \& Prokopec, S. (2009). If you build it will they come?- an empirical investigation of consumer perceptions and strategy in virtual worlds. Electronic Commerce Research, 9(1-2), 115-134. doi:10.1007/s10660-009-9031-7

17. Hamari, Juho, and Lehdonvirta, Vili, Game Design as Marketing: How Game Mechanics Create Demand for Virtual Goods (2010). International Journal of Business Science \& Applied Management, Vol. 5, No. 1, pp. 14-29, 2010.

18. Jung, Y., \& Pawlowski, S. D. (2014). Understanding consumption in social virtual worlds: A sensemaking perspective on the consumption of virtual goods. Journal of Business Research, 67(10), 2231-2238. doi:10.1016/j.jbusres.2014.01.002.

19. Jayasankar Ramanathan and Keyoor Purani, (2014), Brand Extension Evaluation: The Real World and The Virtual World, IIM, Indore.

20. Herrewijn, L., \& Poels, K. (2014). Recall and recognition of in-game advertising: the role of game control. Frontiers in Psychology, 4. doi:10.3389/fpsyg.2013.01023

21. Haenlein, M., \& Kaplan, A. M. (2009). Flagship Brand Stores within Virtual Worlds: The Impact of Virtual Store Exposure on Real-Life Attitude toward the Brand and Purchase Intent. Recherche et Applications En Marketing (English Edition), 24(3), 57-79.

22. Hamari, J., Alha, K., Järvelä, S., Kivikangas, J. M., Koivisto, J., \& Paavilainen, J. (2017). Why do players buy in-game content? An empirical study on concrete purchase motivations. Computers in Human Behavior, 68, 538-546. https://doi.org/10.1016/j.chb.2016.11.045

23. Hamari, J., \& Keronen, L. (2017). Why do people buy virtual goods: A meta-analysis. Computers in Human Behavior, 71, 59-69. doi:10.1016/j.chb.2017.01.042

24. Julie M. Pharr, (2011), A Research Agenda For Investigating the Effectiveness of Branding in Virtual Reality, Tennessee Tech University,

25. Kaplan, A. M., \& Haenlein, M. (2009). Consumer Use and Business Potential of Virtual Worlds: The Case of "Second Life." International Journal on Media Management, 11(3-4), 93-101. http://doi.org/10.1080/14241270903047008

26. Kaplan, Andreas M., and Michael Haenlein (2010), "Users of the World, Unite! The Challenges and Opportunities of Social Media," Business Horizons, 53 (1), 59-68
27. Mattsson, J., \& Barnes, S. (2008). Brand Value in Virtual Worlds: An Axiological Approach. Paper presented at EMAC 37:th annual Conference, Brighton, United Kingdom.

28. Mäntymäki, Matti \& Salo, Jari. (2015). Why do teens spend real money in virtual worlds? A consumption values and developmental psychology perspective on virtual consumption. International Journal of Information Management. 35. 124-134. 10.1016/j.ijinfomgt.2014.10.004.

29. Messinger, P. R., Stroulia, E., Lyons, K., Bone, M., Niu, R. H., Smirnov, K., \& Perelgut, S. (2009). Virtual worlds - past, present, and future: New directions in social computing. Decision Support Systems, 47(3), 204-228. doi:10.1016/j.dss.2009.02.014

30. Shen, Jia and Eder, Lauren B. (2019) "Intentions to Use Virtual Worlds for Education," Journal of Information Systems Education: Vol. 20 : Iss. 2 , Article 11.

31. Muzellec, L., Lynn, T. and Lambkin, M. (2012), "Branding in fictional and virtual environments", European Journal of Marketing, Vol. 46 No. 6, pp. 811-826.

32. Mennecke, B. E., Mcneill, D., Ganis, M., \& Townsend, A. M. (2008) Second Life and Other Virtual Worlds : A Roadmap for Research Second Life and Other Virtual Worlds : A Roadmap for Research. CAIS - Communications of the Association for Information Systems, 22(March 2008), 371-388.

33. Messinger, P. R., Stroulia, E., Lyons, K., Bone, M., Niu, R. H., Smirnov, K., \& Perelgut, S. (2009). Virtual worlds - past, present, and future: New directions in social computing. Decision Support Systems, 47(3), 204-228. http://doi.org/10.1016/j.dss.2009.02.014

34. Muzellec, L., Lynn, T. and Lambkin, M. (2012), "Branding in fictional and virtual environments", European Journal of Marketing, Vol. 46 No. 6, pp. 811-826.

35. Odih, P. (2007). Advertising in Modern and Postmodern Times. London,California,New Delhi: SAGE Publications Ltd. Retrieved from http://eprints.gold.ac.uk/6352/ Patent issued for providing advertising in a virtual world. (2013). Marketing Weekly News,, 494.

36. Pannicke, D., \& Zarnekow, R. (2009). Virtual Worlds. Business \& Information Systems Engineering, 1(2), 185-188. http://doi.org/10.1007/s12599-008-0016-1

37. Papp, R. (2011). Virtual worlds and social networking: Reaching the millennials. Journal of Technology Research, 2, 1

38. Park, S.R., Nah, F.F. and Jeon, S. (2008), "Virtual world affordances: enhancing brand value", Journal of Virtual Worlds Research, Vol. 1 No. 2 , available

http://journals.tdl.org/jvwr/index.php/jvwr/article/view/350/267 (accessed 19 January 2014).

39. PCPRO (2010), "Whatever Happened to Second Life?" available at: www.pcpro.co.uk/features/354457/whateverhappened- to-second-life/4 (accessed 15 May 2014).

40. Pearce, C. and Artemesia (2009), Communities of Play - Emergent Cultures in Multiplayer Games and Virtual Worlds, MIT Press, Cambridge, MA.

41. Reynolds, J. (2008), "It may be a second life - but product quality is still number one in the Armidi shopping village", The Retail Digest, Vol. 15 summer, pp. 34-39.

42. Richins, M.L. (1994), "Valuing things: the public and private meaning of possessions", Journal of Consumer Research, Vol. 21 No. 3, pp. 504-521.

43. Romeo, J.B. (1991), "The effect of negative information on the evaluations of brand extensions and the family brand", In Holman, R.H and Solomon, M.R. (Eds), Advances in consumer research (Vol. 18), Association for Consumer Research, Provo, UT, pp. 399-406, available at: www.acrwebsite.org/search/view-conference-proceedings.

44. Štavljanin, Velimir \& Cvijovic, Jelena \& Kostic-Stankovic, Milica. (2017). Research of indirect advertising in video game industry. Industrija. 45. 113-132. 10.5937/industrija45-16065.

45. Shirin, Artyom \& Gustav, Puth. (2011). Customer satisfaction, brand trust and variety seeking as determinants of brand loyalty. AFRICAN JOURNAL OF BUSINESS MANAGEMENT. 5. 10.5897/AJBM11.2380

Published By:

Blue Eyes Intelligence Engineering \& Sciences Publication (C) Copyright: All rights reserved. 


\section{AUTHORS PROFILE}

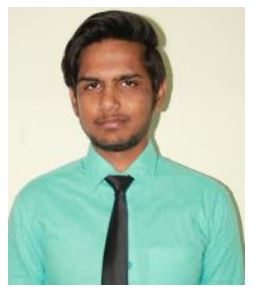

Mr. Shubham Shaurav, is pursuing a master's of business administration (MBA) and completed his Bachelor's degree (BBA Hons.) with marketing and Finance as dual specialization from Lovely Professional University. He has experience in marketing \& has demonstrated a history of working in the internet industry. Over the past three years, working on Strategist Marketing with different brands and understanding the mindset of the customers acquire the knowledge and experience how a small change can create your presence unique, effective and rewarding.

As a marketing professional he dream to influence the life of every human being on this planet using his skills and have potential to bring happiness in their lives.

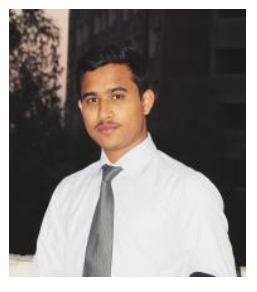

Mr. Sanaullah Mallick, is pursuing a master's of business administration (MBA) and completed his Bachelor's degree (BBA Hons.) with marketing and finance as dual specialization from Lovely Professional University. He is having an analytical bent of mind always trying to dive deep into things, truly passionate about work. with strong educational background. He also worked on a lot of project in managent service such as consulting a firms for international explanation, marketing strategy building for ongoing business, and also contributed his part to develop the client/customer base of big brand.

As a management professional he has a vision to bulid disruptive growth strategies for business. 